\title{
EU-Ukraine "deep" trade agenda: the effectiveness and impact perspectives
}

\section{Maryna Rabinovych ${ }^{1}$}

Accepted: 8 February 2022

(c) The Author(s), under exclusive licence to Springer Nature Limited 2022

\begin{abstract}
The EU-Ukraine deep and comprehensive free trade area (DCFTA) is marked by an impressive scope of regulatory approximation and market integration. Nonetheless, the performance of the DCFTA often tends to be assessed through the sole prism of changes in the volume of trade between the parties. This paper seeks to complement such an approach by an in-depth investigation of EU-DCFTA's performance from the effectiveness and impact perspectives. It finds that the EU-Ukraine "deep" trade agenda is marked by medium effectiveness, with the strongest concerns, attributed to corruption, weak rule of law and strong oligarchic influence. At the same time, the DCFTA had been a strong engine for trade-related reforms (e.g. countering technical barriers to trade; public procurement; competition and state aid) in Ukraine over the period from 2014 to 2019. Yet, the reforms' tempo slowed down after the most recent presidential elections, with numerous changes pending in the domains of transport and infrastructure, financial sector reform and customs reforms. Nonetheless, the EU-Ukraine DCFTA is found to exert a considerable impact on the interplay of the regulatory spaces and influences in the regions and the role of the EU as a trade power.
\end{abstract}

Keywords EU $\cdot$ Ukraine $\cdot$ Trade $\cdot$ Effectiveness $\cdot$ Legislative approximation

\section{Introduction}

Signed by the Parties in 2014, the EU-Ukraine association agreement (AA) "is the most ambitious agreement that the EU has ever developed with any partner" (EU Neighbours East 2020). The EU-Ukraine deep and comprehensive free trade agreement (DCFTA) is marked by an impressive scope of Ukraine's aspired Single Market integration and the related regulatory approximation. Alongside this, the EU has

Maryna Rabinovych

Maryna.rabinovych@uia.no; marinarabi93@gmail.com

1 Department of Political Science and Management, University of Agder, Tollbodgata,

65A 4614 Kristiansand, Norway 
funded numerous assistance projects in Ukraine, aimed at supporting the DCFTArelated reforms. The DCFTA's ambitious scope and the EU's sectoral approach to supporting its implementation turn the EU-Ukraine "deep" trade agenda" into a powerful instrument of facilitating internal reforms in Ukraine.

Nevertheless, the performance of the EU "deep" trade agenda often tends to be assessed through the prism of changes in the volume of trade between the parties. This article seeks to complement such a dominant "trade-only" approach with an in-depth analysis of how the EU performs in terms of the EU-Ukraine "deep" trade agenda from the effectiveness and impact perspectives. To this end, it brings together three inter-related literature strands, namely the organizational management and public administration studies; the European Studies and the development studies. Hereby we understand effectiveness as goal attainment (Héritier 2012), whereas impact signifies the policy's problem-solving capacity and its ability to shape the environment, within which the actors operate (Strange 1987).

Assessing the implementation of the EU-Ukraine "deep" trade agenda, we find that the DCFTA had been a strong engine for trade-related reforms (e.g. countering technical barriers to trade, public procurement, and competition) in 2014-2019. Yet, the reforms' tempo slowed down after the most recent presidential elections, with numerous changes pending in the domains of transport, transport infrastructure, postal and courier services, and the financial sector, and customs reforms. Nonetheless, the EU-Ukraine "deep" trade agenda has already made a noteworthy contribution to bringing Ukraine's regulatory space closer to the EU norms, and the effort to balance the economic, environmental and social aspects of sustainable development in Ukraine. Beyond the doubt, the DCFTA can be regarded as a promising legal gateway for Ukraine to deepen its integration into the EU's Single Market. In broader theoretical terms, the case of the EU-Ukraine trade relations is illustrative of the multiplicity and intertwined nature of the political, legal and development effects, produced by the EU “deep" trade agreements.

\section{Theoretical framework and key concepts}

The problématique of performance assessment is of high and permanent value for the EU's strategy- and policy-making (Baltag and Romanyshyn, 2018). A particular relevance of this endeavour for the $\mathrm{EaP}$ is determined by at least three reasons. Firstly, the EaP is a complex initiative, as it involves six countries with divergent political regimes, and economic and foreign policies. Secondly, all the EaP countries are experiencing political and/or territorial conflicts of different gravity, such as the Armenia-Azerbaijan conflict over Nagorno-Karabakh, the conflict between Lukashenko and the pro-democratic forces in Belarus, and the Ukraine crisis.

\footnotetext{
1 For the purposes of this paper, the term "the EU-Ukraine "deep" trade agenda" is considered to encompass three aspects: (i) the norms of the EU-Ukraine DCFTA; (ii) the unilateral financial and technical assistance instruments the EU uses to support the DCFTA's implementation and (iii) the prospects of further deepening trade between the EU and Ukraine.
} 
Thirdly, since the outbreak of the latter conflict, the exercise of the EaP became increasingly strained by geopolitical concerns (Ferguson 2018). These challenges make it relevant to look at the EaP's unintended consequences and the structural changes it has produced in the region.

As mentioned earlier, the article approaches the EU-Ukraine "deep" trade agenda from the standpoint of three literature strands: public administration and organization studies; European studies and development studies. The literature on organizational management and public administration is utilized to define performance and the ways to assess it, while the European Studies literature offers an insight into how scholars approach the EU performance in different policy domains. Additionally, the development studies perspective is useful for tracing the effects of the $\mathrm{EaP}$ in light of the sustainable development goals (SDGs).

\section{Organizational management and public administration}

The measurement and evaluation of performance are central to the organizational management and public administration literature. Originally, the assessment of organizational performance was primarily centered on profitability (e.g. Lusthaus et al., 2002, p.5). Later on, the organizational studies have seen the rise of multiaspect conceptualizations of performance, embracing the output and input dimensions of organizational activities and their relation to the external environment. Nevertheless, there is still "little consensus as to what constitutes a valid set of criteria" for measuring and evaluating performance.

Therefore, both the organizational management and public administration studies scholars tend to operationalize performance through specific criteria. For instance, the "three Es" performance assessment model encompasses the criteria of economy, effectiveness and efficiency (Carter, et al. 2002, p.40). Thereby "economy" signifies the costs related to production (i.e. input costs), and effectiveness deals with the attainment of policy goals (i.e. the output dimension). Efficiency brings together the input and output dimensions by looking at the best possible use of the input costs. Once again referring to effectiveness and efficiency, the four-element model by Lusthaus et al. (2002) supplements these two criteria with two more: relevance and financial viability. In turn, the performance assessment model, suggested by Baltag and Romanyshyn (2018) to analyze the EaP performance, comprises five elements, namely policy relevance, cohesion, effectiveness, impact, and resilience. This analysis will primarily focus on the outputs, namely "effectiveness" and "impact" perspectives.

The literature on policy-making and public policy analysis links effectiveness to the attainment of initially set policy goals. A similar understanding of effectiveness is common for the organizational management studies (Lusthaus, et al., 2002). The key challenges, concerned with exploring and measuring policy effectiveness, deal with the vaguely formulated policy goals, the presence of mutually contradicting goals, and varying time limits, associated with the goals. In contrast to effectiveness, the "impact" criterion enables an analyst to capture the whole spectrum of effects the policy produced beyond its formal goals. In the literature on public policy, impact is 
commonly associated with the policy's problem-solving capacity and its structural power, i.e. the ability to shape the environment in which both the actor, exercising the policy, and other actors operate in a long-term perspective (Strange 1987). Notably, the attainment of a policy goal does not mean that it generated a meaningful and sustainable impact. The other way round, the fact that the policy has led to changes in the external environment and the conditions, within which divergent actors operate does not predetermine the attainment of its goals. As shown below, particularly the impact criterion is emphasized in both the studies of the EU performance in various foreign policy domains and in the development studies. The shared reason for such an emphasis is that both the EU external policies and development policies (broadly defined) aim at creating long-term sustainable effects. The challenges of assessing policy impact stem from the difficulty of determining the causal links between the policy and the researched changes, as well as applying the counter-factual reasoning to see what the situation would have been, if there had been no policy.

For the measurement purposes, the paper will apply the three-value measurement scale, whereby the effectiveness and impact of the EU-Ukraine "deep" trade agenda can be assessed as "high", "moderate" or "low". High effectiveness implies full compliance and/or rule implementation, while high impact means that the policy has solved the problems it aimed to solve, and has achieved the profound and irreversible transformation. In turn, moderate effectiveness signifies the partial attainment of policy goals, while the moderate impact is about partial problem-solving, implying the changes' reversibility. Low effectiveness and low impact refer to the policy's failure to attain its initial objectives and the persistence of initial problem and the lack of structural effects, respectively.

\section{European studies. the ENP and eastern partnership}

Performance assessment matters for the whole spectrum of the EU policies and activities, ranging from the EU's response to the COVID-19 pandemic (Rhinard, 2020) to the Union's performance in international organizations (Oberthür and Rabitz, 2014). Nonetheless, many contributions in the European Studies domain zoom in on a single dimension of performance, rather than comprehensively assess a policy's performance. This is the frequent case for effectiveness - a usual target (and critical point) in the studies of the EU external relations, in general, and the ENP and EaP, in particular (e.g. Chaban, et al. 2013). Similarly, a number of studies have analyzed the impact, generated by various aspects of the ENP/EaP (Monastiriotis, et al., 2014; Tiganasu, et al. 2020). Besides, the impact dimension of the ENP/EaP is featured in two major literature sub-strands:

Europeanization and transformation By analogy with the EU Enlargement policy, the key desired impact of ENP/EaP is the profound transformation in the Eastern Neighbourhood. Content-wise, it encompasses political change (i.e. oriented to democracy, the rule of law and the observance of human rights), the transition to the market economy, and the approximation of a country's legislation to the acquis communautaire. The long-term convergence process Neighbours undergo to achieve such a transformation is addressed in literature as Europeanization. Lavenex and 
Schimmelfennig (2009) define Europeanization as the process of the EU rules' selection, adoption and application in the partner countries. The Europeanization literature demonstrates the EU's ability to promote functional cooperation and transfer its rules to the Neighbourhood countries in the related policy domains (Freyburg, et al., 2011). Nonetheless, there is a consensus among the EU Studies and Area Studies scholars that the Europeanization has its limits, and the transformation in the Eastern Partnership countries remains incomplete (e.g. Mylovanov and Van Weelden 2018).

EU structural power. The EU structural power concept focuses on the idea of structures as benchmarks to assess the EU's impact in different country contexts and policy domains. Keukeleire understands structures as "relatively permanent organizing principles (such as "capitalism" or "democracy") that condition the various sectors of human activities at various levels and to the operationalisation of these principles through a complex constellation of institutions, laws, habits, etc." (Metais et al., 2013, p.7). In turn, structural power means an actor's power to shape such structures in a long-term perspective - an ability that lies at the heart of achieving high impact. Similar to the literature on Europeanization, the structural power literature acknowledges the EU's noticeable yet limited impact in the region (e.g. Tyushka 2017).

In sum, the effectiveness and impact aspects of the ENP/EaP are touched upon in various sub-strands of the EU Studies literature, yet the application of these concepts as performance criteria in these domains is highly limited, and will benefit from the above insights from the organizational management and public administration literature.

\section{Development studies}

In its Staff Working Document accompanying the Commission's Communication on next steps for a sustainable European future, the Commission refers to the ENP/ $\mathrm{EaP}$ as the pathways to foster the implementation of the Sustainable Development Goals (SDGs) externally. ${ }^{2}$ The literature on the ENP/EaP, however, seldom explores the ENP/EaP effectiveness and impact in light of the SDGs implementation, while focusing on the European integration and Europeanization purposes (Rabinovych, 2019). It is suggested to complement the above perspective with the development studies angle for several interconnected reasons. Firstly, both the ENP and the EaP, more specifically, are marked by comprehensive nature that excludes zero impact on SDGs implementation and sustainable development in the region. This statement is of importance for the EU's DCFTAs with Ukraine, Moldova and Georgia, as they encompass multiple trade-related disciplines and concern virtually all domains of the economic activities. Subsequently, the assessment of the effectiveness, impact and resilience of the EU "deep" trade agenda in any of the Eastern Neighbourhood countries would be incomplete without an insight into the implications for the

\footnotetext{
${ }^{2}$ Commission Staff Working Document "Key European action supporting the 2030 Agenda and the Sustainable Development Goals", SWD/2016/0390final of 22.11.2016.
} 
SDGs' implementation in the region. Last but not least, given the long-term nature of the EU development engagement and aid to third countries, the development policy practice and scholarship are capable of offering useful insights for the assessment of the EU's performance in relation to the "deep" trade agenda in Ukraine (e.g. Kim and Lightfoot, 2017; Carbone 2013).

In a nutshell, the development studies perspective serves as complementary to the perspectives, addressed above, and seeks to broaden our outlook of how the "deep" trade agenda performs.

\section{Case Study: EU “deep" trade agenda in Ukraine}

\section{EU “deep" trade agenda in Ukraine: context, objectives, legal basis and components}

The EU-Ukraine DCFTA forms the part of the AA, signed in 2014 and implemented since $2017 .^{3}$ The EU-Ukraine AA is a highly ambitious international agreement, envisaging a profound political dialogue between the Parties and their cooperation and convergence in a foreign policy domain, as well as "deep" trade liberalization and regulatory approximation. Title VII of the AA "Institutional, general and final provisions" highlights the multilevel and complex institutional structure of the Agreement, including the Association Council, the Association Committee, as well as the Parliamentary Association Committee. The roadmap for the AA's implementation is constituted by the 2015 EU-Ukraine Association Agenda that contains Ukraine's commitments to multiple political and economic reforms, such as the constitutional reform, election reform, judicial reform, deregulation, and the reform of public procurement. ${ }^{4}$ Though the AA contains ambitious political commitments and has "enhanced the adaptability of the national constitutional order to the European integration project and European common values" (Petrov, 2018, p.99), the following analysis will concentrate on the trade dimension of the Agreement. The key reason to focus on the "deep" trade agenda deals with the fact that, despite the DCFTA's unique "depth" and Single Market integration prospects it offers, its effectiveness and impact tend to be considered in literature from a solely economic, rather than also political science, legal and management perspectives (Matuszak, 2019; Olekseyuk and Balisteri 2018). The study thus promises to provide a more comprehensive picture of the effectiveness and impact, delivered by the "deep" trade agenda.

Notably, the history of the EU-Ukraine bilateral relations, including economic cooperation and legislative approximation dates to the 1994 EU-Ukraine Partnership and Cooperation Agreement (PCA). ${ }^{5}$ The PCA set the framework for

\footnotetext{
3 Association Agreement between the European Union and its Member States, of the one part, and Ukraine, of the other part. OJ L 161/3 of 29/05/2014 (hereinafter referred to as the EU-Ukraine AA).

4 EU-Ukraine Association Council, EU-Ukraine Association Agenda as endorsed on 16 May 2015. https://eeas.europa.eu/archives/docs/ukraine/docs/st06978_15_en.pdf. Accessed 6 December 2021.

5 ECSC, Euratom: Council and Commission Decision of 26 January 1998 on the conclusion of the Partnership and Cooperation Agreement between the European Communities and their Member States, of the one part, and Ukraine, of the other part, 98/149/EC. OJ L 49, 19.2. 1998, 1-2.
} 
political dialogue between the Parties and their economic cooperation. Art. 10(1) PCA required the Parties to "accord to one another the most-favoured nation treatment" as formulated by the general agreement on tariffs and trade (GATT). Moreover, the Agreement contained provisions regarding labour, the establishment and operation of companies, and cross-border supply of services between the Community and Ukraine, including the provisions as to legislative approximation (e.g. Art. 51(2) PCA). The approximation of laws got momentum with the 2004 ENP Action Plan that, inter alia, provided for the "gradual removal of restrictions and non-tariff barriers that impede bilateral trade" and the improvement of the business climate (European Commission 2005). By the year 2008, when Ukraine joined the WTO (with the EU's technical support) and the EU and Ukraine started the DCFTA negotiations, there has already been an initial legal and cooperation basis to proceed with the "deep" agenda.

The EU-Ukraine DCFTA, concluded in 2014 as a part of the EU-Ukraine AA, is, thus, the cornerstone of the EU-Ukraine "deep" trade agenda. According to Art. 1(d) of the EU-Ukraine AA, the DCFTA pursues two intertwined policy goals:

to establish conditions for enhanced economic and trade relations leading towards Ukraine's gradual integration in the EU Internal Market and to support Ukrainian efforts to complete the transition into a functioning market economy by means of, inter alia, the progressive approximation of its legislation to that of the Union.

The achievement of the above goals is promoted by several peculiarities of the EU-Ukraine DCFTA. ${ }^{6}$ This is, first of all, in-detail substantive standards within the "deep" disciplines, such as competition, public procurement and sustainable development.Secondly, the DCFTA is subject to two types of conditionality, namely the common values and market access conditionality. The former conditionality type is the common values conditionality that links trade liberalization benefits to Ukraine's observance of fundamental values. This conditionality type is present across a broad spectrum of the EU trade agreements, yet the suspension of trade liberalization is utilized by the EU quite seldom and as a measure of last resort. In turn, the DCFTA uses the so-called "market access conditionality" to make the opening of the EU's market to Ukraine conditional on its implementation of the legislative approximation obligations. On top of that, the implementation of the DCFTA is secured by the operation of the monitoring, consultations and dispute settlement mechanism. ${ }^{7}$ Alongside the DCFTA, we suggest distinguishing two more components, constitutive of the EU-Ukraine "deep" trade agenda, namely the EU's support to the DCFTA norms' implementation and the prospects of deepening the EU-Ukraine trade relations beyond the existing legal framework. The former component entails the EU's sectoral technical assistance; direct financing of the so-called 'reform posts' in the ministries through the EU public administration reform (PAR) initiative, as well as

\footnotetext{
${ }^{6}$ EU-Ukraine AA, Part IV, Chapter 13.

7 EU-Ukraine AA, Art. 475-477.
} 
the support for small and medium-sized enterprises (SMEs) and civil society (Wolczuk and Zeruolis 2018).

Moreover, Art. 463 EU-Ukraine AA provides the Association Council with the right to update or amend annexes to the AA, "taking into account the evolution of EU law" but "without prejudice to the specific approximation provisions of [the DCFTA]". As illustrated by Van der Loo (2020), a comprehensive update of the DCFTA constitutes a challenge for the Parties, given the AA's complexity and the Association Council's limited competencies to substantially broaden or deepen the Parties' association relations. So far, the Association Council agreed only on several amendments to annexes, for example, with respect to sanitary and phytosanitary measures, public procurement, customs, and energy (Van der Loo 2020, pp.11-12). Alongside these rather legalistic changes, the Parties have recently entered into the process of updating the trade-related part of the EU-Ukraine AA and getting Ukraine involved in the implementation of the EU Green Deal (President of Ukraine 2021). The Ukrainian stakeholders' key expectations from the AA update encompass the reduction or elimination of customs duties and quotas used by the EU in various sectors (e.g. agribusiness), the conclusion of the Agreement on Conformity Assessment and Acceptance of Industrial Products (ACAA), and further legislative approximation on selected issues (e.g. waste transportation) (Centre of United Actions, 2021). Though the exact extent and scope of the planned update are difficult to predict, the prospect of the AA/DCFTA update represents and gives an impetus to the Ukrainian Party to strengthen its compliance with the AA (President of Ukraine 2021).

To conclude, the EU "deep" trade agenda constitutes a comprehensive and flerxible multi-aspect framework, designed to pursue the long-term policy goals pertaining to Ukraine's Single market integration and its market economy transition.

\section{Effectiveness}

As mentioned earlier, literature understands effectiveness as "goals attainment". Therefore, finding out, whether the EU "deep" trade agenda has been effective requires setting the results of the "deep" trade agenda's implementation against the EU's and Ukraine's jointly agreed goals, provided for in the DCFTA. An important preliminary remark to be made is that the DCFTA has been only implemented in Ukraine since 2017, and Ukraine has time to implement many of the DCFTA-related commitments until 2024. ${ }^{8}$ Moreover, the unveiling of the DCFTA's full potential is hampered by the ongoing conflict in Eastern Ukraine and the implications of global crises, such as the corona-crisis. Partly due to these factors, and more specific challenges, addressed below, the effectiveness of the "deep" trade agenda can be assessed as medium, whereby the goals of the initiative were attained only partly.

The first declared goal of the DCFTA deals with establishing the conditions for advancing the EU-Ukraine economic and trade relations in a way that they contribute to Ukraine's gradual Internal Market integration. As an ambitious "integration

\footnotetext{
${ }_{8}$ The analysis is only relevant for the time period until June 2021.
}

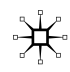


without membership" framework (Petrov et al., 2015), the DCFTA undoubtedly creates (at least, the legal and institutional) conditions for the advancement of the EU-Ukraine economic and trade relations. This statement can be substantiated by the fact that the DCFTA contains norms as to liberalizing trade in goods and trade in services between the Parties and gradually granting them access to the public procurement markets of each other. Moreover, it provides for extensive regulatory approximation in various domains, such as non-tariff barriers to trade, competition, public procurement, trade, and sustainable development, so those businesses both in the EU and Ukraine can make actual use of the DCFTA. As noted above, the EU supports Ukraine's legislative approximation to the acquis communautaire in these domains with multiple sectoral technical assistance projects and capacity-building activities, thus, once again contributing to the goal of "creating conditions" for the advancement of EU-Ukraine economic ties.

While the DCFTA fulfils the goal of creating conditions for strengthening the EU-Ukraine trade and economic ties, and Ukraine's Single Market integration, the EU-Ukraine rapprochement in trade and economic domains is concerned with considerable obstacles. As it will be highlighted in more detail in the following section on the impact of the EU-Ukraine "deep" trade agenda, the reorientation of Ukraine's trade from the markets of Russia and the commonwealth of independent countries (CIS) countries to the EU market has been concerned with significant costs. Coupled with the challenge of the conflict in Donbas - Ukraine's most industrialized region-, and now the COVID-19 crisis, the costs of a massive trade reorientation have prevented an increase in the EU-Ukraine trade from having generated massive welfare gains. As to the long-term economic gains and expected welfare effects of the DCFTA, economists offer different prognoses, yet warning against the overestimation of the economic gains the bilateral liberalization of trade with the EU will bring Ukraine, even if Ukraine's integration into the Single Market becomes deeper (Oleskyuk and Balisteri 2018; Nekhay, et al. 2020). Alongside this, the limitations of the welfare gains, expected from trade liberalization and Ukraine's Single Market integration, can be linked to Ukraine's continuing complex transition to market economy. Hence, there is a consensus among scholars and policy analysts that the progress of reforms, needed for transition remains mixed, with the anti-corruption domain causing the strongest concern (Ibid).

The referral to Ukraine's incomplete transition to market economy offers a good point to start with the analysis of an extent to which the DCFTA has managed to "support Ukrainian efforts to complete the transition into a functioning market economy". The scholarly and analysts' consensus as to the incompleteness of Ukraine's transition to a market economy demonstrates that the "deep" trade agenda with the EU failed to act as a catalyst for a quick transition (at least as for mid-2021, four years since the DCFTA had been fully implemented) (Mylovanov and Weelden 2018). This would, however, be even hardly possible, given the profound and longlasting nature of challenges to market economy transition in Ukraine, such as corruption, weak rule of law and excessive oligarchic. Various oligarchic clans are, inter alia, considered to purposefully undermine Ukraine's cooperation with international partners, such as the EU and the IMF (Iwański, 2017). Although Ukraine is to a considerable extent "lost in transition" (Mylovanov and van Weelden, 2018), 
particularly the "deep" trade agenda has given crucial impetus to several policies and legal processes, essential for the transition. This is, for instance, the creation of an open and transparent electronic tendering system "Prozorro", competition law reform and the strengthened autonomy of the Anti-Monopoly Committee, the introduction of the state aid regime and the unbundling of the gas transmission system. Moreover, the data of the monitoring system "Pulse of the Agreement" demonstrates uneven rates of the Ukraine's approximation of its legislation to the acquis communautaire, ${ }^{9}$ with significant delays in the domains of customs, financial sector reform and consumer protection-this also testifies to the partial effectiveness of legislative approximation as a key means of supporting Ukraine's transition to the market economy.

In sum, the effectiveness of the EU-Ukraine "deep" trade agenda can be assessed as a medium, with the strongest concerns, attributed to the formal nature of rules' implementation, corruption, weak rule of law, and strong oligarchic influence.

\section{Impact}

The impact performance criterion relates to the policy's problem-solving capacity and its structural power/structural effects, rather than the fact of it having achieved the initial policy goals (i.e. the effectiveness dimension, explored above). Hence, we will look at the impact, delivered by the "deep" trade agenda in trade and economic, sustainable development, legal and political terms, with an emphasis on the agenda's capability to solve pressing problems and lead to structural changes.

Trade and economic impact.

As for 2019, “the EU is Ukraine's largest trading partner, accounting for more than $40 \%$ of its trade in 2019" (European Commission 2020a). For the EU, Ukraine is the $19^{\text {th }}$ largest partner for the exports of goods $(1 \%)$ and the 20 th-for imports (1\%). While the total EU-Ukraine trade reached a considerable milestone of EUR 43.3 bln in 2019, the COVID-19 pandemic is expected to have considerably hindered trade between the Parties (European Commission, 2020a). Nonetheless, the moderate increase of the Ukrainian exports (20\%) to the EU between 2013 (the last year before the signing of the DCFTA) and 2018 (the first full year after the DCFTA entered into force) could already be regarded as a success amid the negative developments in the external environment. Such developments include, for instance, the outbreak of the violent conflict in Eastern Ukraine; the government's loss of control over Crimea and part of the Donbas region, as well as the decrease of the global commodity prices for the key export goods, such as grains and metal (Dabrowski, et al., 2020). Given the "depth" of the ongoing legislative approximation, an example of exports dynamics in 2013-2018 provides experts with moderate optimism as to the post-pandemic prospects. Although the EU has long been a large investor in Ukrainian economy (with the overall volume of investments, accounting for 16.4

\footnotetext{
9 These data is available under the link: https://pulse.kmu.gov.ua/.
}

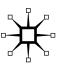


billion in 2014), the DCFTA's impact on foreign direct investment (FDI) over the period from 2013 to 2018 is being assessed as limited (Nekhay, et al., 2020).

A pronounced dimension of the EU-Ukraine "deep" trade agenda's structural impact (in both trade and political terms) has been the re-orientation of Ukraine's trade from the markets of Russia and the Commonwealth of Independent States (CIS) to the EU market. In 2012, 25.7 percent of Ukrainian exports went to the Russian market, while the exports to the EU accounted for $24.9 \%$. By 2019, the EU's share of Ukrainian exports had reached 42.6 percent, whereas the Russia's share had fallen to $7.7 \%{ }^{10}$ The share of Ukrainian exports to its key non-EU exports destinations (China, Turkey, India, and Egypt) remained relatively stable, with the slight increase of two percent. The trends, characterizing Ukraine's imports over the researched period, have been largely the same with respect to the EU (the rise by more than 10\%) and the Russian Federation (the roughly 20 percent-decrease). In contrast to exports, the imports from non-EU countries (incl. China, Turkey, the USA, Switzerland, and Belarus) had collectively increased by $9 \%$, now constituting exactly the third of Ukraine's imports (Dabrowski, et al., 2020).

The tendency towards the re-orientation of Ukraine's trade to the EU market testifies to the Ukrainian market's adjustment to "deep" trade liberalization with the EU. Nonetheless, the unveiling of the "deep" trade agenda's full potential is hindered by several weaknesses and threats. Firstly, one shall mention the low absolute rates and the drop in Ukraine's exports of services over the recent seven years. ${ }^{11}$ The proliferation of informal structures, as well as the rule of law challenges ${ }^{12}$ condition the low level of the EU-Ukraine investment cooperation, widely regarded as a key to the Central and Eastern European (CEE) countries European integration. Among the potential threats, one can mention the weakening of Ukraine's position at the gas transit market in case the Nord Stream II pipeline project is completed and the negative effects on Ukraine's chemical and metal exports to the EU due to the planned EU's carbon tax (Dabrowski, et al., 2020). Moreover, Ukraine's reorientation from the Russia's and CIS countries' markets to the Western ones has inevitably brought about negative macroeconomic externalities that became particularly perceptible due to the COVID-19 crisis.

\section{Sustainable development}

Agenda 2030 understands sustainable development as comprised of three aspects: economic growth, environmental protection, and social standards (UN General Assembly, 2015). The EU-Ukraine DCFTA inevitably impacts sustainable development in Ukraine both due to its considerable economic impact and an influence on environmental and social standards, exercised, inter alia, via the "Trade and

\footnotetext{
${ }^{10}$ For the up-to-date statistics on Ukraine's external trade, please visit https://oec.world/en/profile/count ry/ukr.

11 Ibid.

12 Ukraine held the 72th position in the World Justice Project (WJP) Rule of Lax Index in 2020, two positions lower compared to 2014 (Betliy, 2020).
} 
Sustainable Development" chapter. As well as the "deep" trade agenda's trade and economic impact, its impact on sustainable development in Ukraine can be assessed as medium. Although the "deep" trade agenda with the EU did not manage to solve Ukraine's major macroeconomic, environmental and social issues, it, however, exerted crucial structural effects on business, energy efficiency and social issues.

The 2020 Ukrainian Voluntary National Review on SDGs immediately acknowledged the link between the DCFTA implementation and some of Ukraine's most recent achievements in the sustainable development domain. Primarily attributed to Goal 8 ("Decent Work and Economic Growth"), such successes include: (i) the 2.9 percent GDP growth rate in 2016-2019; (ii) the roughly 2 percent increase of an employment rate in 2016-2019; (iii) "growth of the share of value added against production costs of SMEs from $58.1 \%$ in 2015 to $64.3 \%$ in 2018 " and an increase in a number of persons, employed by SMEs, by 0,5 million over the period from 2015 to 2018 and (iv) the improvement of Ukraine's position in the Global Innovation Index by 17 places. Moreover, the "deep" trade agenda is portrayed as an engine for the implementation of the environmental protection and resource-saving measures. These measures are, however, reported to have delivered limited impact (e.g. the moderate reduction in the share of resource consumption in 2018 GDP compared to the year 2015) (Ibid, p.75). The effects of a more structural nature were distinguished with respect to the social dimension of sustainable development, including an increase in consumers' satisfaction with the administrative services and the functioning of the justice system or the reduction in the incidence of traumatism at work and sexual violence at work and beyond (Ibid, p.104).

Nonetheless, it is difficult to argue that the EU-Ukraine "deep" trade agenda has managed to act as a high-impact problem-solving tool due to several reasons. Firstly, Ukraine continues suffering from an array of economic challenges, such as the "loss of established intersectoral and logistical ties in the regional and foreign economic space" (Ibid, p.59), an incomplete replacement of losses concerned with market re-orientation or the banking system's low participation in funding SMEs. Furthermore, due to the negative effects of the COVID-19 pandemic, some of the above successes are being 'washed off' (e.g. the rise of the formal employment rate). The impact on business, including its stronger reliance on innovation can be, however, regarded as an achievement of a more structural nature, given the long legacy of the command economy in Ukraine. Secondly, Ukraine has so far implemented only 53 percent of its commitments in the environmental domain. ${ }^{13}$ The key environmental issues, whereby the reforms are pending, include the protection of biodiversity, the governance of genetically modified organisms; the protection of water resources, and the completion of the waste management system reform. ${ }^{14}$ Although the implementation of the "deep" trade agenda is being linked to positive social effects, the scope of the DCFTA's and related programmes' social dimension is highly limited. They do not immediately address housing, access to medical treatment, or the pension system - the most problematic social issues in Ukraine.

13 For Ukraine's AA compliance rates and pending reforms, please visit: https://pulse.kmu.gov.ua/.

14 Ibid. 
In sum, the impact of the EU "deep" trade agenda on sustainable development in Ukraine can be assessed as a medium, with crucial structural effects on SMEs and some social issues, yet the unsustainable economic benefits and an insufficient progress in the environmental domain.

\section{Legal effects}

Based on its own "integration through law" experience, the EU emphasizes the legal dimension of third countries' Single Market integration. We argue that the EU-Ukraine "deep" trade agenda has brought Ukraine's legislation closer to the acquis communautaire and, thus, opened the legal gateway for the country to further deepen its links with the Single Market. The impact of the EU-Ukraine "deep" trade agenda in the legal realm encompasses the following aspects: (i) legislative approximation; (ii) changes as to the conditions for doing business and investment and (iii) broader democracy and rule of law effects.

Ukraine has achieved considerable progress in complying with the substantive legal standards under the DCFTA and/or approximating its legislation to the acquis communautaire in a number of crucial areas. They include, for instance, countering the non-tariff barriers to trade (81\% of tasks completed for 2020); public procurement $(83 \%)$ and statistics and information exchange $(68 \%){ }^{15}$ The progress in these domains is of high relevance for the facilitation of the EU-Ukraine trade in industrial products, the building of common value chains by the EU and Ukrainian businesses, and an unrestricted market access. Other domains are, however, marked by low progress rates. The lowest compliance rates currently mark the financial sector (30\% in 2019 and $53 \%$ in 2020); customs (with a large backlog of commitments that had to be implemented in 2018); transport, transport infrastructure, and postal and courier services (18\% in 2018; $29 \%$ in 2019 and $42 \%$ in 2020). ${ }^{16}$ According to the assessment by the Ukrainian Center for European Policy (UCEP) (2021), the worstperforming sectors with the largest number of "crucial deficiencies" include public health, transport, entrepreneurship, financial cooperation and countering fraud, education and youth policy, and audio-visual policy (p. 2). Uneven compliance rates and the implementation-related delays do not themselves devalue the EU-Ukraine AA as a gateway for the convergence of the EU and Ukraine legal spaces yet hamper the dynamic AA's implementation.

Secondly, the DCFTA-inspired legislative approximation and the promotion of the democratic and rule of law-oriented practices inevitably changed Ukraine's position in the World Bank's Doing Business rating. While in 2014 Ukraine held the 112th position in this rating, in 2020 it reached 64 (Betliy, 2020). In 2020, Ukraine demonstrated the best scores with respect to the "dealing with construction permits" (20th position) and "getting credit" (37th position) criteria, yet "resolving insolvency" (146th position) and "getting electricity" (128th position) remain challenging (World Bank 2020). Moreover, despite some positive developments,

\footnotetext{
15 Ibid.

16 Ibid.
} 
immediately stemming from the EU-Ukraine "deep" trade agenda (e.g. transparent public procurement), the overall rule of law situation in Ukraine did not improve much. This can be, for instance, substantiated by the recourse to the WJP Rule of Law Index (n.d), whereby Ukraine's position fell by two scores over the period from 2014 to 2019. Similarly, not considerable improvement was achieved in the domain of countering corruption (the change from the 142nd to the 126th position in the Corruption Perception Index) (Transparency International, n.d).

Thirdly, while corruption and the weak judiciary considerably undermine the rule of law in Ukraine, the standards, entailed in "deep" free trade agreements, are empirically proven to be capable of promoting the rule of law in partner countries. The DCFTAs' ability to promote democratic standards can be substantiated by the reference to the theory of democracy promotion through functional cooperation, introduced by Freyburg, et al. (2011). Based on an empirical insight into the operation of the EU's rule transfer in the Eastern and Southern Neighbourhoods, Tina Freyburg et al. (2011) concluded that "the adoption of the principles of transparency, accountability and participation in sectoral legislation may, if properly applied, be one step in the mobilization of a more vivid civil society and a stronger societal control of state power, both of which would constitute important preconditions for democracy" (p.1017). As for the rule of law, Rabinovych (2017) highlighted the rule of law effects of the different categories of the EU-Ukraine DCFTA's norms (i.e. the norms on administrative and technical cooperation, the DCFTA "Transparency" chapter and "deep" disciplines, such as public procurement and competition).

In a nutshell, the EU-Ukraine "deep" trade agenda can beyond the doubt be regarded as a legal gateway for the convergence of the EU and Ukrainian legal spaces, with the DCFTA norms' being capable of generating far-reaching democracy and rule of law effects. Nonetheless, the "deep" trade agenda's impact on the rule of law and anti-corruption domains remain limited, and this significantly hinders EU-Ukraine investment cooperation.

\section{Political effects}

As noted in the introduction to the case study, the EU-Ukraine AA has produced strong political effects both at the level of international relations and Ukraine's domestic politics. The former part of this statement can be illustrated by considerable (and dangerous) geopolitical effects of Ukraine's preference to the AA with the EU over the Russia-led Eurasian Economic Union (EEU) following the Euromaidan Revolution in November 2013. Since the Euromaidan and the signing of the AA, Ukraine has continuously been subject to Russia's military, political and economic efforts aimed at getting Ukraine back to its "sphere of influence" (Ferguson 2018). One of the key responses to these developments on the EU side has been a profound change in the EU-Russia relations based on an assumption that "the European Union must learn 'to use the language of power'" (Paikin, 2021). At the domestic level, the AA can be seen as a catalyst to an array of reforms in Ukraine, such as the decentralization reform and the reform of judiciary and law enforcement agencies, extensively analyzed in literature (e.g. Rabinovych, et al. 2018; Popova and Beers 2020). When it comes to the political effects of the EU-Ukraine "deep" trade 
agenda, more specifically, they tend to stem from the re-orientation of Ukraine's exports and imports from the traditional Russian/the Commonwealth of Independent States (CIS) markets to the EU markets. With the EU market becoming the top destination for Ukraine's exports, one can argue that the DCFTA significantly increased EU trade power in the region. This, in turn, means the EU's stronger leverage in Ukraine, both with respect to trade-related reforms and the political developments.

Hereby it shall be stressed that the EU launched the EU-Russia-Ukraine trilateral consultation process at the ministerial level as to the DCFTA in July 2014, yet it did not help to achieve a mutually beneficial compromise. Russia's opposition to the EU-Ukraine AA/DCFTA, the outbreak of the Ukraine crisis obviously led to the deterioration of the EU-Russia relations (Nitoiu, 2016). It has been more than six years since the EU introduced the consistent sanctions policy against Russia over its annexation of Crimea and the support for illegal militants in Eastern Ukraine, and Russia has applied mirror sanctions.

These developments may seem to set a clear stage for the further implementation and potential strengthening of the EU-Ukraine "deep" trade agenda: the EU builds its trade power in Ukraine, Russia loses its leverage, the EU-Russia relations are deteriorating, and the EU seeks new partnerships, yet the reality is more complex due to several considerations. Firstly, the Ukrainian leadership seems to be tired of EU conditionality and the uncertainty as to the EaP future, so the violations of political conditions, set by the EU, become ever more audacious (such as the Constitutional Court's attempt to destroy the electronic asset declaration system in December 2020) (Sukhov, 2020). Secondly, there are Ukrainians, being disillusioned about the Euromaidan revolution and the EU foreign policy course, and such a disillusionment is being supported by opposition politicians that become ever more popular (e.g. the pro-Russian Opposition Platform "For Life") (Lennon 2020). Moreover, the Ukraine-Russia bilateral economic and business networks are still strong, and, if the pro-Russian parties get more support, there would be voices in favour of re-orienting trade back to the Russian and CIS countries' markets. Thirdly, one shall not equate the EU-Russia relations to the ones between Russia and the EU Member States. The support for restoring and strengthening economic ties in Russia across some of the EU Member States can be also seen as a factor that may change the current political dynamics around the implementation of the EU-Ukraine DCFTA. Last but not least, changes in such political dynamics may also stem from the third countries (e.g. China's and Turkey's) increasing leverage in Ukraine.

Hence, the political impact of the EU-Ukraine AA can be assessed as a medium. Although it has produced considerable structural changes in the short-term perspective, they can be potentially reversed due to the complex political constellations in the region. 


\section{Conclusion}

The aim of this article has been to assess the effectiveness and impact of the EUUkraine "deep" trade agenda in Ukraine, including the DCFTA, the related EU's unilateral support instruments, and the prospects for Ukraine's Single Market integration. To conduct such an assessment, we brought together the insights from organizational management and public administration, European Studies and development studies.

As a result, we found that the EU-Ukraine "deep" trade agenda is marked by medium effectiveness, with strongest concerns, attributed to corruption, weak rule of law and strong oligarchic influence. "Deep" trade with the EU has exerted multi-aspect impact in Ukraine in trade and economic, sustainable development, legal and political terms. Although the EU-Ukraine trade liberalization led to the notable increase in the EU's share in both Ukrainian exports and imports, Ukraine still suffers from negative economic externalities due to the abrupt reorientation from the Russia's and CIS countries' markets to the Western ones. Alongside this, the weaknesses in trade terms include low levels of Ukraine's services' exports to the EU and EU-Ukraine investment cooperation. The noteworthy threats deal with the potential weakening of Ukraine's position at the gas transit market if Nord Stream-2 project is completed and the challenges to exports due to the EU planned carbon tax. From the sustainable development perspective, the "deep" trade agenda has not so far managed to solve Ukraine's major macroeconomic, environmental and social problems. It, however, exerted crucial structural effects on business (i.e. the rise of the SMEs' role and their stronger reliance on innovation) and some of the social issues (e.g. public services and justice). In legal terms, the EU-Ukraine DCFTA can be regarded as a crucial legal gateway for Ukraine's Single Market integration and the convergence of the EU and Ukrainian legal spaces. Although the "deep" trade agenda was found capable of exerting important indirect legal impact on the democratic and rule of law practices in Ukraine, the rule of law challenges and high corruption rates serve as crucial obstacles to unveiling the DCFTA's potential. In political terms, the "deep" trade agenda expectedly boosted EU's trade power in Ukraine, yet it is still prone to uncertainties, such as Russia's multiaspect pressure on Ukraine, the persistence of frequently informal Ukraine-Russia bilateral links and the unclear future of the EaP.

In a nutshell, the three years of DCFTA's implementation demonstrated the mixed account of its effectiveness and impact amid the complex political and rule of law uncertainties, yet time and policy resilience may help the EU-Ukraine "deep" trade agenda deliver more in trade, sustainable development, legal and political terms. The prospect of the AA update may be seen as giving a strong impetus to Ukraine's improvement of its compliance with the AA, in general, and the DCFTA, more specifically, and an increase in the DCFTA's effectiveness and impact.

\section{Declarations}

Conflict of interest The author confirms that there is no conflict of interest. 


\section{References}

Baltag, D., and I. Romanyshyn. 2018. The challenge of analyzing the performance of the European Neighbourhood policy. In The Routledge handbook on the European Neighbourhood policy, ed. T. Schumacher, A. Marchetti, and T. Demmelhuber. London: Routledge.

Betliy, O. 2020. Overview of macroeconomic trends in Georgia, Moldova and Ukraine under the Association Agreements since 2014. 3 DCFTAs Project, 8 July, http:/www.ier.com.ua/files/publications/ Articles/2020/Betliy\%202020\%20Macro\%20DCFTA.pdf, accessed 25 June 2021.

Byberg, R. 2019. The history of the integration through law project: Creating the academic expression of a constitutional legal vision for Europe. German Law Journal 18 (6): 1531-1556.

Carbone, M. 2013. Between EU actorness and aid effectiveness: The logics of EU Aid to Sub-Saharan Africa. International Relations 27 (3): 341-355.

Carter, N., P. Day, and R. Klein. 2002. How organizations measure success: The use of performance indicators in Government. London: Routledge.

Centre for United Actions. 2021. Association agreement with the EU: Needs assessment of Ukrainian Exporters, May 2021, https://centreua.org/wp-content/uploads/2021/09/policy-brief.pdf, accessed 6 December 2021.

Chaban, N., O. Elgström, and M. Knodt. 2013. Perceptions of EU mediation and mediation effectiveness: Comparing perspectives from Ukraine and the EU. Cooperation and Conflict 54 (4): 506-523.

European Commission. 2005. EU-Ukraine - strengthening the strategic partnership, https://ec.europa.eu/ commission/presscorner/detail/en/MEMO_05_57, accessed 28 January 2021.

European Commission. 2020b. Joint statement following the 22nd EU-Ukraine Summit, 6 October 2020b, https://ec.europa.eu/commission/presscorner/detail/en/IP_20_1849, accessed 28 January 2021.

European Commission. 2020a. Countries and regions. Ukraine, https://ec.europa.eu/trade/policy/count ries-and-regions/countries/ukraine/\#: :text=Trade $\% 20$ picture, $\%$ E2\%82\% AC19.1\%20bn\%20in\% 2020a19, accessed 28 January 2021.

European Commission (n.d) EU-Ukraine deep and comprehensive free trade area, https://trade.ec.europa. eu/access-to-markets/en/content/eu-ukraine-deep-and-comprehensive-free-trade-area, accessed 28 January 2021.

Dabrowski, M., Domínguez-Jiménez, M. and G. Zachmann (2020) Six years after Ukraine's Euromaidan: reforms and challenges ahead, Bruegel policy contribution, 30 June 2020, https:/www.bruegel.org/ 2020/06/six-years-after-ukraines-euromaidan-reforms-and-challenges-ahead/, accessed 28 January 2021.

Delcour, L. 2015. The 2015 ENP Review: beyond stocktaking, the need for a political strategy. College of Europe Policy Blog, 1 December 2015, http://aei.pitt.edu/92684/1/delcour_cepob_1-15_0.pdf, accessed 28 January 2021.

Emerson, M., Movchan, M. (eds.). 2018. Deepening EU-Ukraine relations. What, Why and How? London: Rowman and Littlefield, Part II.

EU Neighbours East. 2020. EU and Ukraine discuss results of 2019 association agreement implementation, https://www.euneighbours.eu/en/east/stay-informed/news/eu-and-ukraine-discuss-results2019-association-agreement-implementation\#: :text=Welcoming\%20the\%20government's\%20pro gress\%20in,ever\%20developed\%20with\%20any\%20partner, accessed 28 January 2021.

Ferguson, I. 2018. Between news spheres of influence: Ukraine's geopolitical misfortune. Geopolitics 23 (2): 285-306.

Freyburg, T., S. Lavenex, F. Schimmelfennig, T. Skripka, and A. Wetzel. 2011. Democracy promotion through functional cooperation? the case of the european neighbourhood policy. Democratization 18 (4): 1026-1054.

Héritier, A. 2012. Policy effectiveness and transparency in european policy-making. In The Oxford handbook of the European Union, ed. E. Jones, A. Menon, and S. Weatherhill, 676-689. Oxford: Oxford University Press.

Iwański, T. 2017. The Oligarchs strike back. New Eastern Europe 2, https://www.ceeol.com/search/artic le-detail?id=535490, accessed 20 June 2021.

Kim, S., and S. Lightfoot. 2017. The EU and the negotiation of global development norms: The case of aid effectiveness. European Foreign Affairs Review 22 (2): 159-175.

Lavenex, S., and F. Schimmelfennig. 2009. EU Rules beyond EU Borders: Theorizing external covernance in European Politics. Journal of European Public Policy 16 (6): 791-812. 
Lennon, O. 2020. Six reasons the "opposition platform" won in Eastern Ukraine. Kennan Kable, https:// www.wilsoncenter.org/publication/kennan-cable-no-45-six-reasons-the-opposition-platform-woneastern-ukraine, accessed 28 January 2021.

Van der Loo, G. 2020. Cath me if you can: updating the eastern partnership association agreements and the DCFTAs. 3 DCFTAs, https:/www.ceps.eu/wp-content/uploads/2020/05/GVDL-and-TA-Updat ing-AA-DCFTAs.pdf, accessed 6 December 2021.

Lusthaus, C, Adrien, M., Anderson, G. and G. Montalvan (eds). 2002. Organizational assessment: A framework for improving performance. Ottawa: the Interamerican Development Bank.

Matuszak, S. 2019. Real integration - impact of the DCFTA on trade between Ukraine and the European Union. International Issues Slovak Policy Affairs XXVIII 1-2: 84-93.

Metais, R., Thépaut, Ch. and S. Keukeleire (eds.) .2013. The European union's rule of law promotion in its neighbourhood: A structural Foreign policy analysis. EU Diplomacy Papers 04/2013, http://aei. pitt.edu/42925/1/edp_4_2013_metais_thepaut_keukeleire1.pdf, accessed 28 January 2021.

Monastiriotis, V., Kalioras, D. and G. Petrakas. 2014. The regional impact of EU association agreements : lessons for the ENP from the CEE experience. LEQs Paper No 80, https://papers.ssrn.com/sol3/ papers.cfm?abstract_id=2510426, accessed 28 January 2021.

Mylovanov, T., van Weelden, R. 2018. Ukraine appears to be lost in transition and elites are loving it. Kyiv School of Economics, https://medium.com/@KSE/kse-voice-ukraine-appears-to-be-lost-intransition-reforms-and-elites-are-loving-it-5132ea74fd6c, accessed 28 January 2021].

Nekhay, O., Delgado, M. C. and Cardenete, M. 2020. Does abolishing tariffs in bilateral trade matter for a country's economic growth? the impact of the EU-Ukraine DCFTA. Europe-Asia Studies. Online First.

Nitoiu, C. 2016. Towards conflict or cooperation? the Ukraine crisis and EU-Russia relations. Southeast European and Black Sea Studies 16 (3): 375-390.

Oberthür, S., and F. Rabitz. 2014. On the EU's performance and leadership in global environmental governance: The case of the Nagoya protocol. Journal of European Public Policy 21 (1): 39-57.

Olekseyuk, Z., and E. Baliesteri. 2018. Trade liberalization gains under different trade theories: A case study for Ukraine. Empirica 45: 507-542.

Paikin, Z. 2021. EU-Russia relations and Europe's global profile. CEPS, https://www.ceps.eu/eu-russiarelations-and-europes-global-profile/, accessed 6 December 2021].

Peters, B.G. 2018. Policy problems and policy design. Cheltenham: Edward Elgar.

Petrov, R. 2018. The impact of the EU-Ukraine association agreement on constitutional reform and judicial activism in Ukraine. Review of Central and Central East European Law 43 (2): 99-115.

Petrov, R., G. Van der Loo, and P. Van Elsuwege. 2015. The EU-Ukraine association agreement: A new legal instrument of integration without membership? Kyiv-Mohyla Law Politics Journal 1: 1-19.

Popova, M., and D.J. Beers. 2020. No revolution of dignity for Ukraine's judges: judicial reform after the Euromaidan. Demokratizatsiya the Journal of Post-Soviet Democratization 28 (1): 113-142.

President of Ukraine. 2021. Relations between Ukraine and the EU today are at one of the highest points in history, https://www.president.gov.ua/en/news/vidnosini-ukrayini-ta-yes-sogodni-perebuvayutna-odnij-z-naj-66461, accessed 6 December 2021.

Rabinovych, M. 2019. EU's development policy vis-à-vis Ukraine after the Euromaidan: Securitization state-building and integration. East European Politics 35 (3): 322-350.

Rabinovych, M., Levitas, A., Umland, A. 2018. Revisiting decentralization after Maidan: Achievements and challenges of Ukraine's local governance reform. Kennan Institute, accessed 6 December 2021.

Rabinovych, M. 2017. The rule of law promotion through trade in the "associated" eastern neighbourhood. Polish Yearbook of International Law XXXVII: 71-100.

Resource and analysis center "society and environment", DiXi Group, Institute for economic research and policy consulting. 2020. European green deal: opportunities and threats to Ukraine, http://www.ier. com.ua/files/publications/Policy_papers/IER/2020/european-green-dealenfinal_IER_com_ua.pdf, accessed 28 January 2021.

Rhinard, M. 2020 Assessing the European Union's Performance in the COVID-19 Pandemic. LSE Blog, https://blogs.lse.ac.uk/europpblog/2020/03/26/assessing-the-european-unions-performance-in-thecovid-19-pandemic/, accessed 28 January 2021.

WJP rule of law index (n.d) Ukraine, https://worldjusticeproject.org/rule-of-law-index/country/2020/ Ukraine/, accessed 28 January 2021.

Strange, S. 1987. The persistent myth of lost hegemony. International Organization 41 (4): 551-574. 
Sukhov, O. 2020. Constitutional court destroys Ukraine's asset declaration system. Kyiv Post, https:// www.kyivpost.com/ukraine-politics/constitutional-court-cancels-public-asset-declarations-illicitenrichment-law.html?cn-reloaded=1, accessed 28 January 2021.

Tiganasu, R., T. Jijie, and K. Kourtit. 2020. Effectiveness and impact of cross-border cooperation programmes in the perception of beneficiaries investigation of Romania-Ukraine-Moldova programmes. Regional Sci Policy Pract. 12 (5): 867-891.

Transparency International (n.d.) Corruption Perceptions Index, https://www.transparency.org/en/cpi/ 2020/index, accessed 28 January 2021.

Tyushka, A. 2017. Building the neighbours: The EU's new association agreements and structural power in the eastern neighbourhood. J Contemp Central Eastern Eur 25 (1): 45-61.

United Nations general assembly. 2015. Resolution "transforming our world: the 2030 agenda for sustainable development", A/RES/70/1, https://sdgs.un.org/2030agenda, accessed 28 January 2021.

Wolczuk, K., Žeruolis, D. 2018. Rebuilding Ukraine. An Assessment of EU assistance, Chatham house research paper, https://www.chathamhouse.org/sites/default/files/publications/research/2018-08-16rebuilding-ukraine-eu-assistance-wolczuk-zeruolis.pdf, accessed 28 January 2021.

World Bank. Economic profile Ukraine. 2020. Doing Business 2020, https://www.doingbusiness.org/ content/dam/doingBusiness/country/u/ukraine/UKR.pdf, accessed 28 January 2021.

Publisher's Note Springer Nature remains neutral with regard to jurisdictional claims in published maps and institutional affiliations. 